\title{
Marker assisted rice breeding for resistance to biotic and abiotic stressors
}

\author{
Elena Dubina ${ }^{1, *}$, Pavel Kostylev ${ }^{2}$, Sergey Garkusha ${ }^{1}$, Margarita Ruban ${ }^{1}$, and Dmitry \\ Pischenko ${ }^{1}$ \\ ${ }^{1}$ Federal Scientific Rice Centre, Belozerny, 3, Krasnodar, 350921, Russia \\ ${ }^{2}$ Agrarian scientific center «Donskoy», Nauchny Gorodok, 3, Zernograd, 347740, Russia
}

\begin{abstract}
Due to the fact that blast (causative agent - Pyricularia oryzae $C a v$.) is considered to be one of the harmful diseases of rice around the world, weeds compete with the crop for light, mineral nutrition and space, the accelerated development of resistant genotypes for these stressors is very relevant. The use of modern biotechnological approaches (molecular marking) is promising and especially in demand in breeding rice varieties of a new generation. This article presents the results on the introduction and pyramiding in the same genotype blast resistance genes $P i-1, P i-2, P i-$ 33, $P i-t a, P i-b, P i-40$ and the gene for tolerance to prolonged flooding $S u b$ $1 \mathrm{~A}$, as a weed control factor, based on domestic rice varieties Flagman, Snezhinka, Novator, Boyarin, as well as large-grain lines, with a short growing season VNIIR5242, KP-25-14, KP-163 and VNIIR9678. As a result of the volumetric work using marker control of target genes in the genotypes of hybrid plants, 4 modern varietal samples and more than 400 backcross self-pollinated rice lines with introduced and pyramided blast resistance genes, as well as backcross self-pollinated lines with $P i$ and Sub1A genes, were obtained. These plants are adapted for cultivation in the south of Russia, have a duration of 115-117 days, a height of 87-100 cm, a mass of 1000 grains -30 or more grams, a yield of $8.5-11 \mathrm{t} / \mathrm{ha}$, which is significantly higher than that of the standard variety Flagman.
\end{abstract}

\section{Introduction}

The onset of blast caused by the phytopathogenic fungus Pyricularia oryzae Cav. is one of the most dangerous rice diseases worldwide. The development of the disease under ordinary conditions can contribute to a decrease in yield and grain quality from 5 to $25 \%$, and with epiphytotia, losses can be from 60 to $90 \%$ [1,2].

Weeds compete with the rice crop for elements of mineral nutrition, space, light and are one of the main limiting factors that reduce yield. Therefore, today, production requires varieties resistant to the above listed stressors.

\footnotetext{
* Corresponding author: lenakrug1@,rambler.ru
} 
The use of modern biotechnological approaches (molecular marking) in this direction allows accelerating the process of developing such varieties and quickly introduce them into production [3].

The introgression and integration of resistance genes in one genotype into a highly productive domestic germplasm adapted to local conditions of rice cultivation is an informative strategy in the fight against these stressors.

Blast resistance genes $P i-1, P i-2, P i-33, P i-40, P i-t a, P i-b$, located on chromosomes 11 , $6,8,6,12$, and 2, respectively, determine resistance to P. oryzae in the South of Russia [46]. Foreign scientists have identified informative flanking SSR markers closely linked to the above genes [7-10], and we, together with colleagues from VNIISB (Moscow), have developed intragenic molecular markers for the Pi-ta and Pi-b genes $[11,12]$, which are recommended for practical breeding.

Gene Sub1A, discovered by Asian scientists (link), determines the tolerance of rice plants to prolonged flooding with water and can be used to control weeds [13-17].

This will allow developing rice genetic sources for cultivation using environmentally friendly technologies, without the use of highly toxic fungicides and herbicides.

In this regard, the aim of the study: to develop, on the basis of DNA technology, valuable rice genetics sources with economically valuable traits that are resistant to biotic (blast) and abiotic (tolerance to prolonged flooding, as a factor in controlling weeds) stressors and good milled rice quality .

\section{Methods of research}

In program for the development of blast resistant rice varieties, the rice lines C104-LAC, C101-A-51-LAC, C101-LAC, IR-8-2-10-2 IR-36 were used as donors, which have the resistance genes $P i-1, P i-2, P i-1+P i-33, P i-40, P i-b, P i-t a$, respectively [1]. As the maternal forms, the Russian rice varieties Flagman, Snezhinka and Boyarin were used. In the frameworks of program on development of rice varieties tolerant to prolonged flooding, variety of foreign breeding Khan Dan (Vietnam) served as donor for introduction of Sub1A gene into domestic rice germplasm. As a maternal form for hybridization early ripening rice varieties and lines with duration of no more than 100-105 days were selected: rice variety Novator as well as large-grained early ripening rice lines KP-163, VNIIR9678, VNIIR5242 and KP-25-14.

When conducting molecular genetic studies, genomic DNA from plant cells by the Murray and Thompson method, using the main lysing buffer of cetyltrimethylammonium bromide [5].

The amplification was carried out in the "Tercyc" and "Bio Rad" D-amplifiers, PCR conditions were optimized.

The separation of the amplification products was carried out by electrophoresis in an $8 \%$ polyacrylamide gel (PAAG) at a voltage of $3.9-4.5 \mathrm{~V} / \mathrm{cm} \mathrm{[16].}$

Visualization of the results of electrophoretic separation of PCR products was performed with use of ethidium bromide (BrEt) in UV light and photographed with digital camera. To determine the length of amplified fragments molecular mass marker was used: $100 \mathrm{bp}+1,5 \mathrm{~Kb}+3 \mathrm{~Kb}$ (SibEnZym).

Hybridization of maternal forms of rice plants was performed with pneumocastration method, pollination - with «Twell»-method [1].

Donor alleles of $P i-1, P i-2, P i-33, P i-40$ genes were visualized by closely linked to them flanking microsatellite markers (sequence taken from NCBI database, available at web-site http://blast.ncbi.nlm.nih.gov/blast.cgi [1]. For identifying Pi-ta, Pi-b genes in hybrid plants intragenic molecular markers were used [9]. 
To identify Sub1A gene primer pairs of flanking microsatellite SSR-markers were used. Their sequence is also taken from NCBI database. It was established that these markers are closely linked to this trait [13-16].

Evaluation of rice donor lines and breeding samples for resistance to local population of $P$. oryzae. Was performed in field conditions of FSI ESOS «Krasnaya» by the predecessor perennial grasses, according to Averyanov's guidelines (1990). As susceptible control varieties Volgogradsky and Pobeda 65 were used, as resistant control - rice variety Avangard.

Depending on the score of damage all varieties were divided into 4 groups: resistant type, medium, susceptible, highly susceptible.

For evaluation on economically valuable traits all agro technical works were performed by the common methods [17].

\section{Results of research}

For 10 years, in the laboratory of information, digital and biotechnologies of Federal Scientific Rice Centre, using molecular marking methods, as part of the program to develop varieties resistant to bio- and abiotic stressors, a wide range of rice germplasm with introduced and pyramided genes with blast resistance and tolerance to prolonged flooding was obtained. A number of backcrosses, accompanied by marker control of target genes based on PCR analysis, as well as field tests, allowed obtaining rice lines with blast resistant genes and genes with tolerance to prolonged flooding (Fig. 1, 2).

From figure 1, we can see that plants \#\# 31, 40, 35t, 16, 24 and 18, obtained from combination KP-163 $\times$ IR 83260-2-10-5-2-1-B, have a dominant allele of $P i-40$ gene in the genotype; plants $64,70,67,69,7,21,35 \mathrm{sv}, 11,39,4,6,63$ - homozygous by recessive. By the results of marker analysis from the selection of 44 plants the following ratio was obtained: 13 hybrid plants had dominant allele of Pi-40 gene in homozygous state in their genotype, 21 - in heterozygous, 10 plants - homozygous by recessive, which corresponds to Mendel splitting $1: 2: 1$.

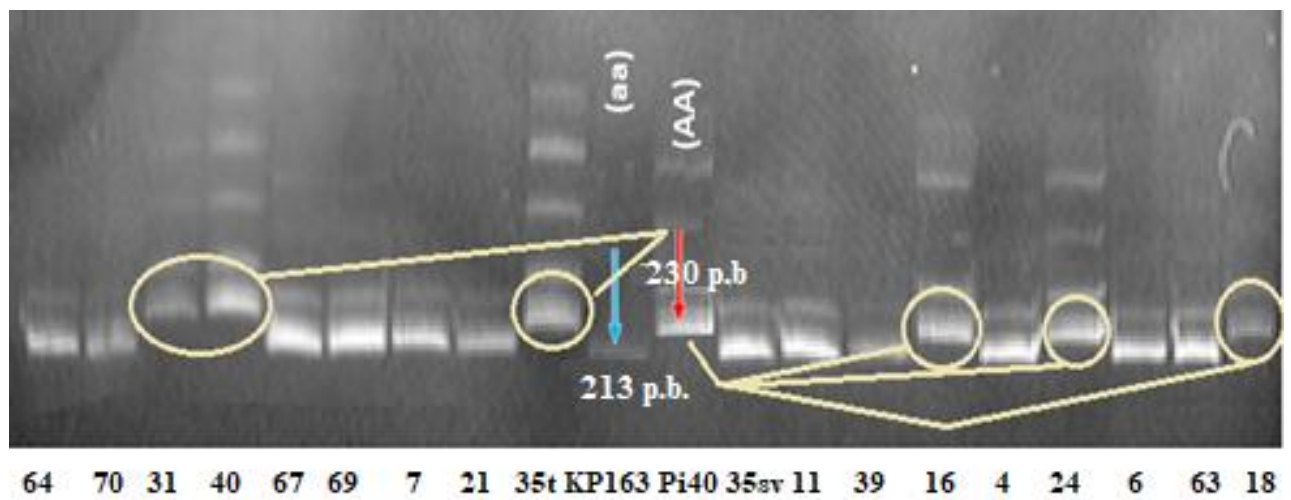

$64 \ldots 18$ - analyzed hybrid plants of BC2F4-population;

$\mathrm{KP}-163$ - large-grained, early ripening rice line KP-163;

$\mathrm{Pi}-40$ - line IR 83260-2-10-5-2-1-B - donor of $\mathrm{Pi}-40$ gene;

Red arrow shows donor allele of $P i-40$ gene, blue one - recessive allele.

Fig 1. Results of PCR analysis for the presence of transferred gene of blast resistance Pi-40

Due to the small amount of obtained seeds in this combination, we selected plants with $\mathrm{Pi}-40$ gene in their genotype in homo- and heterozygous state with positive morphometric 
characteristics (growing season of no more than 125 days, plants height $-85-90 \mathrm{~cm}$, panicle length - 15-20 cm, mass of 1000 grains - 26-31 g). In 2020, their study will continue on economically valuable traits in the field conditions.

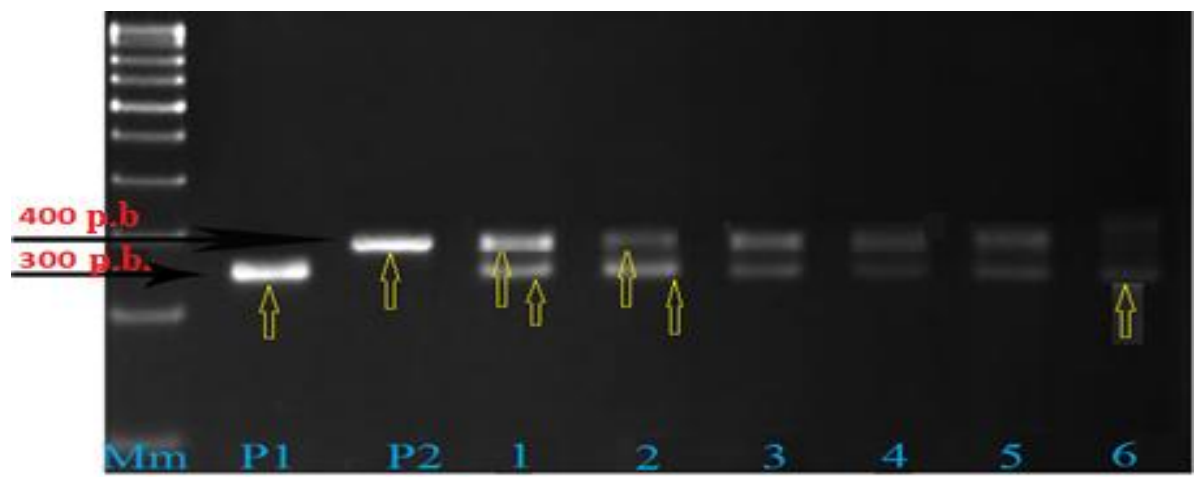

$\mathrm{Mm}$ - marker of molecular DNA mass $100 \mathrm{bp}+1,5 \mathrm{~Kb}+3 \mathrm{~Kb}$ (SibEnZym);

P1 - parent form - rice variety Khan Dan;

P2 - parent form - rice variety Novator;

G1...G6 - hybrid plants of BC2F4-population.

Fig 2. PCR-analysis of rice plants from BC2F4-population by Sub1A203 locus

On electropherogram we can see that hybrid plant G6 by locus Sub1A203 has donor allele in homozygous state, other plants by this locus are heterozygous. Plants which had only maternal allele in their genotype were sorted out.

Among hybrid rice plants, with combined $P i$ and $S u b 1 A$ genes, which according to the results of PCR analysis showed the presence of target genes in the genotypes, selection by phenotype was also performed. Phenotype evaluation was performed based on a laboratory rapid method [15]. The seeds of hybrid plants were grown in test tubes. After the sprouts reached a length of $2-3 \mathrm{~cm}$, the plants in the test tubes were completely flooded with water, and for 14 days the plants were evaluated for tolerance to deep immersion of plants under water (Fig. 3 a, b, c).

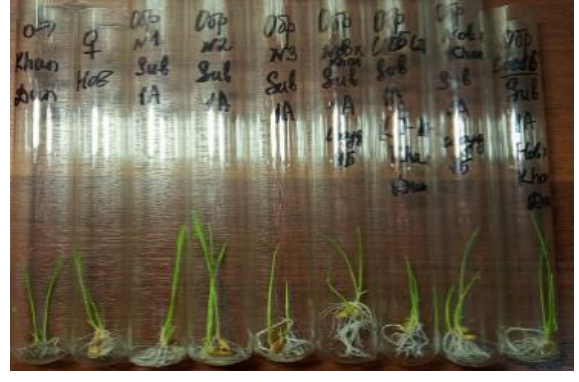

a

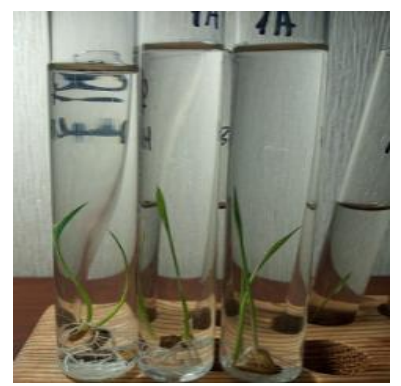

$\mathrm{b}$

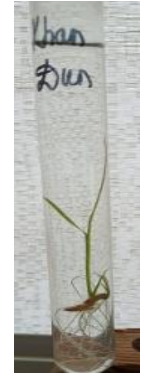

c

Fig 3. Laboratory rapid test method for tolerance to long-term immersion of hybrid rice plants (BC2F4 - generation) with the Sub1A gene under water

As a result of the experiment, plants were selected that, according to DNA analysis, have the Sub1A gene in the genotype and, when assessed by the phenotype, showed tolerance to long-term immersion in water. Such plants were observed to remain in growth when completely submerged under water. After 14 days in the regime of complete flooding, 
the water was emptied from the samples, and within 2-3 days the plants came out of stress. Then they restored their life functions by producing more new leaves.

As part of breeding program and state assignment No. 0494-2019-0001 in 2019, in the competitive variety testing of the third year at FSI ESOS Krasnaya, branch of FSBSI ARRRI, 6 rice varietal samples with blast resistance genes $\mathrm{Pi}$-ta, $\mathrm{Pi}$-2, $\mathrm{Pi}-\mathrm{l}$ were evaluated by the economically valuable traits and resistance to blast.

As a result of severe rejection, two lines with the $P i-2$ gene were selected, one with the $P i$-ta gene and one with the $P i-1$ gene, which have positive indicators for economically valuable traits and are also resistant to the Krasnodar population of $P$. oryzae. The best of them will be submitted to the state variety test in 2020 . The characteristics of these lines by morphometric indicators, blast resistance and milled rice quality are presented in tables 1-3.

Table 1. Characteristics of varieties and some rice lines of competitive variety testing in 2019

\begin{tabular}{|c|c|c|c|c|c|c|c|c|}
\hline $\begin{array}{c}\text { Name of } \\
\text { line/ } \\
\text { variety }\end{array}$ & $\begin{array}{c}\text { Duration, } \\
\text { days }\end{array}$ & $\begin{array}{c}\text { Plant } \\
\text { height, } \\
\mathrm{cm}\end{array}$ & $\begin{array}{c}\text { Number } \\
\text { of } \\
\text { producti } \\
\text { ve stems, } \\
\text { pcs. }\end{array}$ & $\begin{array}{c}\text { Panicle } \\
\text { length, } \\
\mathrm{cm}\end{array}$ & $\begin{array}{c}\text { Number of } \\
\text { spikelets in } \\
\text { panicle, } \\
\text { pcs. }\end{array}$ & $\begin{array}{c}\text { Mass of } \\
\text { grain } \\
\text { from the } \\
\text { plant, g }\end{array}$ & $\begin{array}{c}\text { Mass of } \\
1000 \\
\text { grains, } \\
\mathrm{g}\end{array}$ & $\begin{array}{c}\text { Yield, } \\
\text { t/ha }\end{array}$ \\
\hline KP-8 & $115-117$ & $87.0-90.0$ & 2.9 & $19.0-20.0$ & $136.8-158.1$ & $9.9-10.3$ & $30.2-32.4$ & $8.5-9.5$ \\
\hline KP-9 & $115-117$ & $90.0-95.0$ & 3.1 & $18.2-19.4$ & $126.0-155.6$ & $12.2-12.3$ & $28.6-33.4$ & $8.0-10.0$ \\
\hline KP-27 & $115-117$ & $95.0-100,0$ & 2.9 & $15.4-18.8$ & $94.5-151.0$ & $7.3-11.5$ & $31.7-32.1$ & $8.0-10.0$ \\
\hline KP-34 & $115-117$ & $95.0-100.0$ & 3.1 & $17.9-18.1$ & $124.3-133.7$ & $9.2-10.8$ & $31.8-31.9$ & $10.0-11.0$ \\
\hline $\begin{array}{c}\text { Flagman } \\
(\mathrm{St})\end{array}$ & $115-117$ & $90-95$ & 2.8 & $16.0-18.0$ & $147.0-150.0$ & $1.9-2.0$ & $26.7-28.4$ & $7.5-9.0$ \\
\hline $\mathrm{LSD}_{05}$ & 0 & 0.98 & 0.03 & 1.35 & 19.89 & 1.84 & 2.17 & 0.57 \\
\hline
\end{tabular}

The data in the table show that the plants of the studied varietal samples are adapted to growing conditions in the south of Russia. They have an optimal duration (115-117 days), high panicle spikelet fertility, plant height up to $100 \mathrm{~cm}$, resistant to lodging, as well as to the Krasnodar population of $P$. oryzae (table 2). Their panicle is slightly drooping, compact, with a length from 16 to 20 and more $\mathrm{cm}$. Grain is prolonged (1/b 2.3-2.6), mass of 1000 grains - about 30 and more grams. Milling yield - 71-73\% (table 3). When converted to 1 ha, yield $9.0-11.0$ tons of grain is formed.

The evaluation results of these rice varietal samples for blast resistance are presented in table 2 .

Table 2. Evaluation of rice varietal samples with $P i$ genes for blast resistance in FSI ESOS «Krasnaya», branch of FSBSI «ARRRI» in 2019

\begin{tabular}{|c|c|c|c|c|c|c|c|}
\hline \multirow[b]{2}{*}{$\#$} & \multirow[b]{2}{*}{$\begin{array}{c}\text { Name of } \\
\text { sample }\end{array}$} & \multicolumn{6}{|c|}{ Blast resistance } \\
\hline & & $\begin{array}{c}\# 1 \\
\text { replication }\end{array}$ & $\begin{array}{c}\# 2 \\
\text { replication }\end{array}$ & \begin{tabular}{c|}
$\# 3$ \\
replication
\end{tabular} & $\begin{array}{c}\# 4 \\
\text { replication }\end{array}$ & $\begin{array}{l}\text { Mean } \\
\text { value }\end{array}$ & $\begin{array}{c}\text { Resistance } \\
\text { degree }\end{array}$ \\
\hline 1 & KP-8 & 28,9 & 12,2 & 12,2 & 17,7 & 17,7 & resistant \\
\hline 2 & KP-9 & 24,4 & 8,9 & 18,9 & 15,5 & 16,9 & resistant \\
\hline 3 & KP-27 & 33,3 & 28,9 & 15,5 & 12,2 & 21,8 & resistant \\
\hline 4 & KP-34 & 16,7 & 16,7 & 11,1 & 12,2 & 14,2 & resistant \\
\hline \multicolumn{2}{|c|}{ Flagman, St } & 65,5 & 53,0 & 47,5 & 46,0 & 53,0 & non-resistant \\
\hline \multicolumn{2}{|c|}{$\mathrm{HCP}_{05}$} & 0,09 & 0,11 & 0,09 & 0,19 & 0,01 & \\
\hline
\end{tabular}

The table shows that the selected promising varieties are resistant to the local population of the pathogen $P$. oryzae. On average, their disease development index ranges from 14.2 to $21.8 \%$. 
An assessment of the technological traits (quality) of milled rice of these promising samples was carried out in the rice quality laboratory. The results of the quality evaluation are presented in table 3 .

Table 3. Rsualts of evaluation of milled rice quality of samples with $P i$ genes, studied in FSI ESOS «Krasnaya», branch of FSBSI «ARRRI» in 2019

\begin{tabular}{|c|c|c|c|c|c|c|c|c|c|c|c|}
\hline \multirow[b]{2}{*}{ \# } & \multirow[b]{2}{*}{$\begin{array}{l}\text { Name of } \\
\text { sample }\end{array}$} & \multirow{2}{*}{$\begin{array}{c}\text { Mass } \\
\text { of } 1000 \\
\text { absolu } \\
\text { tely dry } \\
\text { grains }\end{array}$} & \multirow[b]{2}{*}{$\begin{array}{c}\text { Filmi } \\
\text { ness, } \\
\%\end{array}$} & \multirow[b]{2}{*}{$\begin{array}{c}\text { Vitreou } \\
\text { sity, } \\
\%\end{array}$} & \multirow[b]{2}{*}{$\begin{array}{c}\text { Fractu } \\
\text { ring, } \\
\%\end{array}$} & \multicolumn{3}{|c|}{$\begin{array}{c}\text { Grain size, } \\
\mathrm{mm}\end{array}$} & \multirow[b]{2}{*}{$\begin{array}{l}1 / \mathrm{b} \\
\text { ratio }\end{array}$} & \multirow[b]{2}{*}{$\begin{array}{c}\text { Total } \\
\text { milling } \\
\text { yield, } \\
\%\end{array}$} & \multirow{2}{*}{$\begin{array}{c}\text { Head } \\
\text { rice } \\
\text { content, } \\
\%\end{array}$} \\
\hline & & & & & & $\begin{array}{l}\text { length, } \\
\mathrm{mm} \\
\text { (l) }\end{array}$ & $\begin{array}{l}\text { width, } \\
\text { mm } \\
\text { (b) }\end{array}$ & $\begin{array}{c}\text { Thick } \\
\text { ness, } \\
\text { mm } \\
\text { (c) }\end{array}$ & & & \\
\hline 1 & KP-8 & 28,5 & 22,2 & 74 & 13 & 6,7 & 2,9 & 2,0 & 2,3 & 69,7 & 94,8 \\
\hline 2 & KP-9 & 27,7 & 22,3 & 73 & 12 & 6,7 & 2,9 & 2,0 & 2,3 & 69,2 & 94,6 \\
\hline 3 & KP-27 & 28,0 & 22,7 & 75 & 11 & 6,7 & 2,9 & 2,0 & 2,3 & 68,9 & 95,2 \\
\hline 4 & KP-34 & 27,0 & 22,0 & 73 & 18 & 6,6 & 2,9 & 2,0 & 2,3 & 68,7 & 96,0 \\
\hline & $\begin{array}{l}\text { lagman, } \\
\text { St }\end{array}$ & 27,4 & 21,7 & 85 & 28 & 6,0 & 2,8 & 2,0 & 2,1 & 70,7 & 93,2 \\
\hline & $\mathrm{LSD}_{05}$ & 1,51 & 0,16 & 2,96 & 1,97 & 0,19 & 0,18 & 0,22 & 0,22 & 0,82 & 0,70 \\
\hline
\end{tabular}

The data in the table show that the studied varieties belong to the group of mediumgrained varieties. The technological characteristics are not inferior to the standard (milling yield, head rice content). The best of them for testing in 2020 will be transferred to the State Variety Test.

\section{Conclusions}

Based on MAS (breeding with use of molecular markers), rice varieties resistant to blast and tolerance to prolonged flooding as a factor in the weed control, with yields exceeding the standard by $3-5 \mathrm{~kg} / \mathrm{ha}$ and good milled rice quality were developed. The introduction of new varieties in agricultural production will lead to the additional production of more than 600 tons of rice grain for every thousand hectares in the amount of 10 million rubles. At this time, the cost of treating with chemical means of protection against diseases and weeds as a result of reducing the application rate will be significantly reduced.

\section{Authorship Criteria}

The authors of the article confirm that Dubina E.V. has $65 \%$ copyright, Kostylev P.I. $10 \%$, Garkusha S.V. $-10 \%$, Ruban M.G. $-10 \%$, Pischenko D.A. $-5 \%$ and are equally responsible for plagiarism.

\section{Acknowledgments}

We express our deep gratitude to the employees of the rice quality laboratory of the Federal Research Center for Rice for their help and obtaining results on the evaluation of the quality of groats of selection varietal samples. 


\section{References}

1. E.V. Dubina, Zh.M. Mukhina, E.M. Kharitonov, V.N. Shilovskiy, E.S. Kharchenko, L.V. Esaulova, N.N. Korkina, E.P. Maximenko, I.B. Nikitina, Genetika, 51, 881-886 (2015) https://www.doi.org/10.1134/S1022795415060058

2. P.I. Kostylev, A.A. Redkin, E.V. Krasnova, Vestn. Ross. Akad. Skh. Nauk, 1, 26-28 (2014)

3. B. Divya, A. Biswas, S. Robin, R. Rabindran, A.J. Joel, Journal of Genetics, 93, 415-424 (2014) https://link.springer.com/article/10.1007/s12041-014-0395-7

4. Fujita D., Yoshimura A., and Yasui H., Breed. Sci. 60, 18-27 ( 2010) https://doi.org/10.1270/jsbbs.60.18

5. F. Farahzadi, A.Ebrahimi, V. Zarrinnia, R. Azizinezhad, Agric. Res. (2020) https://doi.org/10.1007/s40003-019-00447-1

6. Young-Chan Cho, Soon-Wook Kwon, Im-Soo Choi, Journal of Crop Science and Biotechnology, 10(4), 265 - 276 (2010)

7. S. Ashkani M.Y., Rafii M. Sariah, Genetics and Molecular Research, 10(3), 13451355 (2011) http://dx.doi.org/10.4238/vol10-3gmr1331

8. L.X. Hua, L.Q. Liang, X.Y. He, L. Wang, W.S. Zhang, W. Liu, X.Q. Liu, F. Lin, Biotechnology \& Biotechnological Equipment, 29:3, 448-456 (2015) http://dx.doi.org/10.1186/s12284-016-0091-8

9. Y. Kurokawa, T. Noda, Y. Yamagata, et al. Plant Science., 242, 131 (2016) https://doi.org/10.1016/j.plantsci.2015.09.008

10. I.A. Shilov, O.S. Kolobova, Yu.V. Aniskina, T.V. Shalaeva, N.S. Velishaeva, P.N. Kostylev, E.V. Dubina, Advances in science and technology 30(8), 45-48 (2016) . https://www.elibrary.ru/item.asp?id=26595567

11. I.A. Shilov, Yu.V. Aniskina, N.S. Velishaeva, O.S. Kolobova, T.V. Shalaeva, P.I. Kostylev, E.V. Dubina, Advances in science and technology, 32(11), 21-25 (2018) https://www.elibrary.ru/item.asp?id=36730418

12. S. Abdolhamid, E. M. Septiningsih D. J. M. Abdelbagi M. Ismail, Euphytica, 172, 159-168 (2010) https://link.springer.com/article/10.1007/s10681-009-0014-5

13. L.M. Cuc, L. T. N. Huyen, P.T. M. Hien, V. Hang, N.Q. Dam, P.T. Mui, V.D. Quang, A.M. Ismail, L.H. Ham, Am J Plant Sci., 3, 528-536 (2012) http://doi.org/10.4236/ajps.2012.34063

14. P. Das, K.K. Nutan, S.L. Singla-Pareek and A. Pareek, Frontiers Plant Sci., (2015) https://www.doi.org/10.3389/fpls.2015.00712

15. E.V. Dubina, A.V. Alabushev, P.I. Kostylev, Yu.A. Makukha, M.G. Ruban, I.V. Balyasnyi, Le.H. Ham, D.X. Tu, Le.H. Linh, African Journal of Agricultural Research, 13 (48), 2757-2762 (2018) https://www.doi.org/10.5897/AJAR2018.13563

16. T. Fukao, El. Yeung, and J. Bailey-Serres, The Plant Cell, 23, 412-427 (2011) https://pdfs.semanticscholar.org/abfe/5bf96b20cce4879b18673b0452a301671353.pdf?_ga= 2.173858915.1368528828.1588165678-1152682878.1584369946

17. P.I. Kostylev, Methods of rice breeding, seed production and varietal technique: monograph, 288 (2011). https://www.elibrary.ru/item.asp?id=25128164 